\title{
Do Kombucha Symbiotic Cultures of Bacteria and Yeast Affect Bacterial Cellulose Yield in Molasses?
}

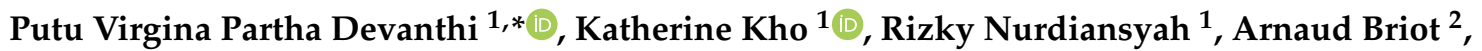 \\ Mohammad J. Taherzadeh ${ }^{3}$ (D) and Solmaz Aslanzadeh 1,*(D) \\ 1 Indonesia International Institute for Life Sciences, Pulomas Barat Kavling 88, Jakarta 13210, Indonesia; \\ katherine.k@i3l.ac.id (K.K.); rizky.nurdiansyah@i3l.ac.id (R.N.) \\ 2 Bioprocess \& Process Engineering Department, Polytech Nantes, University of Nantes, Gavy Océanis, \\ CS 70152, 44633 Saint-Nazaire, France; arnaud.briot@etu.univ-nantes.fr \\ 3 Swedish Centre for Resource Recovery, University of Borås, 50190 Borås, Sweden; \\ mohammad.taherzadeh@hb.se \\ * Correspondence: putu.devanti@i3l.ac.id (P.V.P.D.); solmaz.aslanzadeh@i3l.ac.id (S.A.)
}

Citation: Devanthi, P.V.P.; Kho, K.; Nurdiansyah, R.; Briot, A.;

Taherzadeh, M.J.; Aslanzadeh, S. Do Kombucha Symbiotic Cultures of Bacteria and Yeast Affect Bacterial Cellulose Yield in Molasses? J. Fungi 2021, 7, 705. https://doi.org/ 10.3390/jof7090705

Academic Editor: Laurent Dufossé

Received: 27 July 2021

Accepted: 21 August 2021

Published: 28 August 2021

Publisher's Note: MDPI stays neutral with regard to jurisdictional claims in published maps and institutional affiliations.

Copyright: (c) 2021 by the authors. Licensee MDPI, Basel, Switzerland. This article is an open access article distributed under the terms and conditions of the Creative Commons Attribution (CC BY) license (https:/ / creativecommons.org/licenses/by/ $4.0 /)$.

\begin{abstract}
Bacterial cellulose (BC) is a valuable biopolymer typically observed in Kombucha with many potential food applications. Many studies highlight yeast's roles in providing reducing sugars, used by the bacteria to grow and produce BC. However, whether yeast could enhance the BC yields remains unclear. This study investigates the effect of yeast Dekkera bruxellensis on bacteria Komagataeibacter intermedius growth and BC production in molasses medium. The results showed that the co-culture stimulated $K$. intermedius by $\sim 2 \log \mathrm{CFU} / \mathrm{mL}$, which could be attributed to enhanced reducing sugar utilization. However, $\mathrm{BC}$ yields decreased by $\sim 24 \%$, suggesting a negative impact of D. bruxellensis on BC production. In contrast to other studies, regardless of D. bruxellensis, $K$. intermedius increased the $\mathrm{pH}$ to $\sim 9.0$, favoring the $\mathrm{BC}$ production. Furthermore, $\mathrm{pH}$ increase was slower in co-culture as compared to single culture cultivation, which could be the reason for lower $\mathrm{BC}$ yields. This study indicates that co-culture could promote synergistic growth but results in the $\mathrm{BC}$ yield reduction. This knowledge can help design a more controlled fermentation process for optimum bacterial growth and, ultimately, BC production.
\end{abstract}

Keywords: Komagataeibacter intermedius; Dekkera bruxellensis; co-culture; bacterial cellulose; molasses

\section{Introduction}

Bacterial cellulose (BC) is an extracellular polysaccharide biofilm matrix synthesized by specific types of bacteria. Unlike plant-derived cellulose, BC has a high purity level, as it does not contain lignin, pectin, and hemicellulose. Although BC structure is similar to plant cellulose, it possesses several unique characteristics, including higher crystallinity, Young's modulus, tensile strength, thermal stability, elasticity, and porosity [1,2]. Furthermore, its large surface area increases its water holding capacity and its ability to form strong bonding with other biomaterials, enzymes, and nanoparticles [3]. These features make BC an attractive biopolymer for many applications, especially in food industries [4]. One of the most popular food products derived from BC is known as nata-de-coco, produced by Acetobacter xylinum grown in coconut water [5]. BC also finds promising applications as fat replacer [6,7], texture modifier [8], probiotic and enzyme encapsulating material [9,10], as well as film for food coating and packaging [11,12].

Despite all the unique properties, $\mathrm{BC}^{\prime}$ s high production cost still limits its production at an industrial scale. BC production requires a fermentation medium rich in glucose and other nutrients, which is costly and can account for up to $30 \%$ of the total production cost [13]. Low BC yield and long fermentation time also contribute to the high production cost. Therefore, an alternative cheap fermentation media and suitable microbial cultures are paramount in low-cost BC production at an industrial scale. In recent years, sugarcane 
molasses, a by-product of a sugar refinery, has attracted broad interest as a cheaper alternative fermentation media for BC production. Molasses is known for its high amounts of fermentable sugars, such as fructose, sucrose, glucose, and nutrients such as nitrogen and vitamins, essential for BC formation. However, BC-producing bacteria's ability to break down sucrose, which constitutes $50 \%$ of sugars in molasses, is limited, resulting in lower BC yield. Consequently, expensive pre-treatments would be required, such as acid, heat, or enzymatic treatment [1], to hydrolyse the sucrose before the fermentation process, ultimately leading to higher production costs.

$\mathrm{BC}$ biosynthesis is typically observed during the production of Kombucha, a beverage obtained by fermenting tea and sugar using a symbiotic culture of yeast and acetic acid bacteria. The synergistic interactions between these two microbial groups have been frequently highlighted in the literature [14-17]. Yeast is known as the invertase producer that breaks down sucrose into reducing sugars, increasing their availability to yeast and acetic acid bacteria. These reducing sugars are then metabolized by yeast and acetic acid bacteria into ethanol and organic acids. Glucose, the building block for $\mathrm{BC}$ biosynthesis, is also used by the acetic acid bacteria to produce $\mathrm{BC}$, which is observed as a floating pellicle on Kombucha tea's surface [14]. Although it is tempting to infer that yeast and acetic acid bacteria co-culture could increase the $\mathrm{BC}$ yield, the study supporting this claim is still limited. The yeast-acetic acid bacteria synergistic interactions described above were only reported in the context of Kombucha fermentation, using sucrose as the sole carbon source, with organic acids as the main product of interest $[17,18]$. Moreover, current literature reporting the optimization of $\mathrm{BC}$ production only focus on using acetic acid bacteria in a single culture instead of a co-culture system with yeast [1,2]. Therefore, this study investigates the interaction between Kombucha-derived yeast and acetic acid bacteria in a molasses medium by monitoring growth, $\mathrm{pH}$ changes, and reducing sugar utilization. Since yeast was expected to increase the availability of glucose that serves as a BC building block, the impact of yeast inoculation on $\mathrm{BC}$ yield was also monitored.

\section{Materials and Methods}

\subsection{Materials}

Kombucha culture was provided by PT Tujju Kombucha, Indonesia. The culture was stored at $4{ }^{\circ} \mathrm{C}$ until use. Molasses was supplied by PT Andalan Furnindo, Indonesia, with characteristics presented in Table 1. Black tea (Teh Perbawati Goalpara, Sukabumi, Indonesia), sugar (Gulaku Murni, Indonesia), and pure caffeine (PureBulk, Roseburg, OR, USA) were purchased from the local market in Jakarta. The $\mathrm{pH}$ of molasses was maintained by adding acetate buffer prepared using acetic acid (Merck, Darmstadt, Germany) and sodium acetate (Merck, Darmstadt, Germany). Phosphate Buffer Saline (PBS; Sigma-Aldrich, St. Louis, MI, USA) was used for serial dilution of microbial cells. Microbiological growth media used were Nutrient Agar (NA; Merck, Darmstadt, Germany), Potato Dextrose Agar (PDA; HiMedia, Mumbai, India), and Hestrin and Schramm (HS) comprised of $20 \mathrm{~g} / \mathrm{L}$ glucose, $5 \mathrm{~g} / \mathrm{L}$ peptone, $5 \mathrm{~g} / \mathrm{L}$ yeast extract, $2.7 \mathrm{~g} / \mathrm{L} \mathrm{Na}_{2} \mathrm{HPO}_{4}$, and $1.15 \mathrm{~g} / \mathrm{L}$ citric acid. The bacteria and yeast growth were controlled by supplementing the agar media with chloramphenicol (HiMedia, Mumbai, India) and cycloheximide (Sigma-Aldrich, St. Louis, MI, USA), respectively.

Table 1. Physicochemical characteristics of molasses used.

\begin{tabular}{cc}
\hline Parameter & Molasses \\
\hline Colour & Brown /black \\
Brix, \% & 77.6 \\
Sucrose, \% & 46.9 \\
Inverted sugar, \% & 50.8 \\
Purity, \% & 60.8 \\
Specific gravity, \% & 1.4 \\
pH & 5.1 \\
Ash conductivity, \% & 0.40 \\
\hline
\end{tabular}




\subsection{Methods}

\subsubsection{Kombucha Culture Adaptation in Molasses Medium}

Prior to the isolation step, the Kombucha culture was adapted in the molasses medium to ensure that only the microbes capable of growing and producing $\mathrm{BC}$ in molasses were isolated. The adaptation was carried out gradually in three steps using three different media: (A) 100\% sweetened tea, (B) 50\% sweetened tea and 50\% molasses, and (C) \%100 molasses. Medium A was prepared by boiling $10 \mathrm{~g}$ of black tea and $100 \mathrm{~g}$ of table sugar in $1 \mathrm{~L}$ of type III water. Medium C was prepared by mixing $100 \mathrm{~g}$ of molasses with $1 \mathrm{~L}$ of acetate buffer solution ( $200 \mathrm{mM}, \mathrm{pH} 4.75)$. Medium B was prepared by combining medium $A$ and $C$ to a ratio of 1:1. Before use, each medium was filtered through filter paper $125 \mathrm{~mm}$ $\varnothing$ (cat no 1004125 Whatman) and autoclaved at $121^{\circ} \mathrm{C}$ for $15 \mathrm{~min}$.

The adaptation step started by first transferring the Kombucha culture $(30 \mathrm{~mL})$ to medium A $(300 \mathrm{~mL})$ and incubated at $30{ }^{\circ} \mathrm{C}$ for 7 days until the $\mathrm{BC}$ layer was observed. Then, the culture from medium A $(50 \mathrm{~mL})$ was transferred to $500 \mathrm{~mL}$ of medium B. After 5 days of incubation, the culture from medium B $(50 \mathrm{~mL})$ was transferred to $500 \mathrm{~mL}$ of medium $C$ and incubated for 6 days at the same temperature.

\subsubsection{Microbial Isolation from Adapted Kombucha Culture}

Bacteria and yeast were isolated from both liquid and solid phases (BC). Liquid (1 mL) and BC ( $1 \mathrm{~g})$ were collected and serially diluted using PBS before culturing it on their respective agar media. Bacteria were isolated using NA and $\mathrm{HS}$ agar $(20 \mathrm{~g} / \mathrm{L}$ glucose, $5 \mathrm{~g} / \mathrm{L}$ peptone, $5 \mathrm{~g} / \mathrm{L}$ yeast extract, $2.7 \mathrm{~g} / \mathrm{L} \mathrm{Na}_{2} \mathrm{HPO}_{4}, 1.15 \mathrm{~g} / \mathrm{L}$ citric acid, and $15 \mathrm{~g} / \mathrm{L}$ agar) supplemented with $0.5 \mathrm{mg} / \mathrm{mL}$ cycloheximide. Meanwhile, yeast was isolated using PDA supplemented with $25 \mathrm{mg} / \mathrm{mL}$ chloramphenicol. The agar plates were incubated at $30{ }^{\circ} \mathrm{C}$ for 2-3 days. The dominant colonies were picked from the agar with the highest dilution and subjected to several purification steps by streaking on the same agar media used during isolation. The bacterial cells were Gram-stained before microscopic evaluation, while yeast cells were observed without staining. The pure isolates were cryopreserved in $1.5 \mathrm{~mL}$ of $20 \%$ glycerol solution and kept at $-80{ }^{\circ} \mathrm{C}$ until use.

\subsubsection{Screening for BC-Producing Capacity}

Five bacterial isolates (13.7.KBC.HSA, 13.7.KBC.HSB, 13.7.KBC.HSC, 13.7.KBC.HSD, and 13.7.KBC.HSE) obtained from the previous step were screened for their ability to produce $\mathrm{BC}$. The frozen stocks were revived by plating on HS agar, followed by incubation at $30^{\circ} \mathrm{C}$ for 7 days. After a week, a loopful of each bacterial isolate was transferred to $25 \mathrm{~mL}$ of $\mathrm{HS}$ broth and incubated at $30^{\circ} \mathrm{C}$ for 5 days under static conditions. After 5 days, each isolate's optical density (OD) was measured at $600 \mathrm{~nm}$ and adjusted to $\sim 0.2$, which further served as an inoculum source. The inoculum $(1 \mathrm{~mL})$ was then transferred to each well of 6-well plates containing $9 \mathrm{~mL}$ of molasses medium, comprising $150 \mathrm{~g} / \mathrm{L}$ molasses (70.38 g/L sucrose and $76.14 \mathrm{~g} / \mathrm{L}$ reducing sugars) and $500 \mathrm{mg} / \mathrm{L}$ caffeine in acetate buffer (200 mM, pH 4.75). After 14 days of incubation at $30^{\circ} \mathrm{C}$ under static conditions, the BC yield was examined, and the isolate with the highest $\mathrm{BC}$ producing capacity was selected for further study.

\subsubsection{Identification of Bacterial and Yeast Isolates by DNA Sequencing}

Bacteria and yeast isolates were identified by sequencing the 16S rRNA gene and the D1/D2 region of the $26 \mathrm{~S}$ rRNA gene, respectively. The DNA template was prepared by gene amplification using the colony PCR technique. The $16 \mathrm{~S}$ rRNA gene was amplified using universal primers (27F 5'-AGAGTTTGATCCTGGCTCAG-3' and 1492R 5'GGTTACCTTGTTACGACTT-3'), while the D1/D2 region was amplified using NL1 (5'GCATATCAATAAGCGGAGGA AAAG-3') and NL4 (5'-GGTCCGTGTTTCAAGACGG-3') primers. PCR reactions for $16 \mathrm{~S}$ rRNA gene amplification were performed under the following conditions: $5 \mathrm{~min}$ initial denaturation at $95^{\circ} \mathrm{C}, 34$ cycles of denaturation at $94{ }^{\circ} \mathrm{C}$ for $1 \mathrm{~min}$, annealing at $55{ }^{\circ} \mathrm{C}$ for $1 \mathrm{~min}$, extension $72{ }^{\circ} \mathrm{C}$ for $2 \mathrm{~min}$, and final extension 
at $72{ }^{\circ} \mathrm{C}$ for $5 \mathrm{~min}$. The PCR conditions used for D1/D2 region amplification were as follows: $10 \mathrm{~min}$ initial denaturation at $94^{\circ} \mathrm{C}, 35$ cycles of denaturation at $94{ }^{\circ} \mathrm{C}$ for $1 \mathrm{~min}$, annealing at $52{ }^{\circ} \mathrm{C}$ for $1 \mathrm{~min}$, extension at $72{ }^{\circ} \mathrm{C}$ for $2 \mathrm{~min}$, and final extension at $72{ }^{\circ} \mathrm{C}$ for $10 \mathrm{~min}$. The PCR product was analyzed using electrophoresis with $1 \% w / v$ agarose gel in Tris-borate-EDTA. Agarose gel was then soaked in ethidium bromide (EtBr) and visualized under UV light. Then, the PCR products were sent to Macrogen (Seoul, Korea) for further purification and sequencing. The sequence similarity was then determined using the BLASTn program in the GenBank database (https: / / www.ncbi.nlm.nih.gov/) (accessed on 15 January 2020). The gathered sequences were used to reconstruct a neighbor joining tree (500 bootstraps) with close and distant-related species based on the BLASTn result using MEGAX software [19]. The distant-related species were selected based on identified fungi and bacteria in Kombucha to maintain relevance and some reference sequences [16].

\subsubsection{Bacteria and Yeast Interactions in Molasses Medium}

The selected $\mathrm{BC}$ producing bacteria and yeast interactions were evaluated by comparing their growth in single and co-culture. The experiment was conducted in parallel in several 6-well plates. Each well contained $10 \mathrm{~mL}$ of molasses medium containing $150 \mathrm{~g} / \mathrm{L}$ molasses and $500 \mathrm{mg} / \mathrm{L}$ caffeine dissolved in acetate buffer ( $200 \mathrm{mM}, \mathrm{pH} 4.75)$. Meanwhile, the inoculum of the selected BC producing bacteria and yeast was cultured in HS and PDB liquid media, respectively, for 4 days under a static condition at $30^{\circ} \mathrm{C}$. Different inocula $(5 \%$ $v / v, 10 \% v / v$, and $15 \% v / v$ ) were then added to each well. In the case of co-culture, bacteria and yeast inoculum were combined at a ratio of 1:1. The fermentation was conducted in a static condition at $30{ }^{\circ} \mathrm{C}$ for 15 days. This experiment was repeated on two separate occasions.

\subsubsection{Bacterial and Yeast Cell Enumeration}

Cell enumeration was carried out by taking samples of $0.1 \mathrm{~mL}$, followed by serial dilution in PBS and plating on HS supplemented with cycloheximide and PDA supplemented with chloramphenicol for bacteria and yeast, respectively. Bacteria and yeast colonies were enumerated after $2-3$ days of incubation at $30^{\circ} \mathrm{C}$.

Specific growth rate $\mu\left(\mathrm{h}^{-1}\right)$ were calculated by Equation (1) [20]

$$
\mu=\frac{\operatorname{Ln}\left(X_{0}-X_{t}\right)}{t-t_{0}}
$$

where in:

$X_{t}$ and $X_{0}$ are the microbial population $\left(\mathrm{CFU} \mathrm{mL} L^{-1}\right)$ at $t$ and initial time, respectively $t$ and $t_{0}$ are the $t$ and initial time when the sample is measured, respectively $\mu$ is specific growth rate $\left(1 \mathrm{~h}^{-1}\right)$

\subsubsection{BC Yield Measurement}

After the fermentation, the $\mathrm{BC}$ was collected and oven-dried at $105^{\circ} \mathrm{C}$ for $20 \mathrm{~h}$. The weight measurement was carried out using an analytical balance. To ensure the water was removed entirely, this process was repeated until the stable weight was achieved. The BC yield is expressed as the $B C$ dry weight per volume of the fermentation medium $(\mathrm{g} / \mathrm{L})$.

\subsection{8. $\mathrm{pH}$ and Reducing Sugar Measurement}

The $\mathrm{pH}$ of the medium was measured using a $\mathrm{pH}$ meter. Sugar consumption was monitored by calculating the remaining reducing sugar using the dinitrosalicylic acid (DNS) method. The sample was diluted $100 \times$ with Type III water. Then, $2 \mathrm{~mL}$ of sample was mixed with $1 \mathrm{~mL}$ of 3,5-dinitrosalicylic acid reagent using a vortex. The mixture was boiled for $15 \mathrm{~min}$ and then cooled down in an ice bath before $9 \mathrm{~mL}$ of Type III water was added. The absorbance was then read at $540 \mathrm{~nm}$. 


\subsubsection{Statistical Analysis}

Significant differences among means were tested by one-way analysis of variances (ANOVA) using XLSTAT ${ }^{\mathrm{TM}}$ version 2020.5.1 (Addinsoft, New York, NY, USA) at $p<0.05$ and Tukey's test was applied for means comparison.

\section{Results and Discussion}

\subsection{Screening and Identification of Potential BC Producing Bacteria and Predominant Yeast}

A total of 6 isolates, consisting of 1 yeast (13.7.KBC.HSF) and 5 bacterial isolates (13.7.KBC.HSA, 13.7.KBC.HSB, 13.7.KBC.HSC, 13.7.KBC.HSD, and 13.7.KBC.HSE) were obtained from the Kombucha culture adapted in molasses medium. All bacterial isolates were screened for their $\mathrm{BC}$ producing capacity in molasses medium. The results showed that after 14 days, bacteria isolates 13.7.KBC.HSA and 13.7.KBC.HSB produced 0.018 g/L and $0.019 \mathrm{~g} / \mathrm{L}$ of $\mathrm{BC}$, respectively, which were the highest among the isolates. Although both isolates produced a similar yield, the BC produced by 13.7.KBC.HSB was more brittle. Therefore, 13.7.KBC.HSA was selected as a starter culture for the experiment.

Isolate 13.7.KBC.HSA was subsequently identified through $16 \mathrm{~S}$ rRNA gene sequencing, and the result showed a $99.91 \%$ similarity with the sequence of Komagataeibacter intermedius (Figure 1a). K. intermedius is a Gram-negative rod-shaped bacteria commonly found in fruit juice, wine vinegar, and Kombucha [2,21]. Gaggia et al. [22] reported the presence of K. intermedius and Komagateibacter spp. in Kombucha regardless of the tea types used for the fermentation (black tea, green tea, or rooibos tea). The bacteria is wellknown for its ability to produce $\mathrm{BC}$ with mannitol as the sole carbon source. According to Fernández et al. [2], the K. intermedius strain isolated from a commercial wine vinegar showed $48 \%$ higher BC producing ability than K. xylinus, a commonly used BC producing bacteria. The $\mathrm{BC}$ produced was also free from impurities, exhibited a high crystallinity index, and showed similar mechanical properties to the one produced by K. xylinus. Unlike K. xylinus, K. intermedius is able to produce $\mathrm{BC}$ within a wide $\mathrm{pH}$ range (4-9), and maximum production can occur within a short period in alkaline conditions [21]. In a study by Tyagi and Suresh [1], K. intermedius demonstrated the ability to produce BC in molasses medium; however, the yield was reduced by $\sim 60 \%$ compared to those obtained using pure glucose or fructose medium.

The most dominant yeast isolated (13.7.KBC.HSF) was identified through the D1/D2 region of the 26S rRNA gene sequencing and was shown to have $99.83 \%$ similarity with the sequence of Brettanomyces/Dekkera bruxellensis (Figure 1b). D. bruxellensis is one of the yeast species that is commonly found in Kombucha $[23,24]$ and other fermented products, such as beer [25], wine [26], cider [27], and kefir [28]. This yeast has a complex phenotypic, genotypic, and population structure, which can vary based on the substrate, isolation origin, and geographical origin, suggesting the anthropic influence of the species' diversity [29]. $D$. bruxellensis has been considered industrially important due to its high resistance to osmotic and ethanol stress, the ability to grow in oxygen-limited environments, and low $\mathrm{pH}$. It also demonstrates the ability to produce biofilm with characteristics known to be straindependent [30]. The genetic sequence analysis of different $D$. bruxellensis strains reveals that they are equipped with a gene cluster comprising of a nitrate transporter, nitrate reductase, nitrite reductase, and two $\mathrm{Zn}(\mathrm{II})_{2} \mathrm{Cys}_{6}$ type transcription factors that enable the utilization of nitrate as a sole nitrogen source [31-33]. Such a cluster might allow the yeast to thrive in low-nitrogen environments like molasses. $D$. bruxellensis is also capable of utilizing sucrose efficiently due to the expression of a high-efficiency sucrose transporter, which allows $D$. bruxellensis to outcompete Saccharomyces cerevisiae in sucrose-based fermentations [34,35]. 

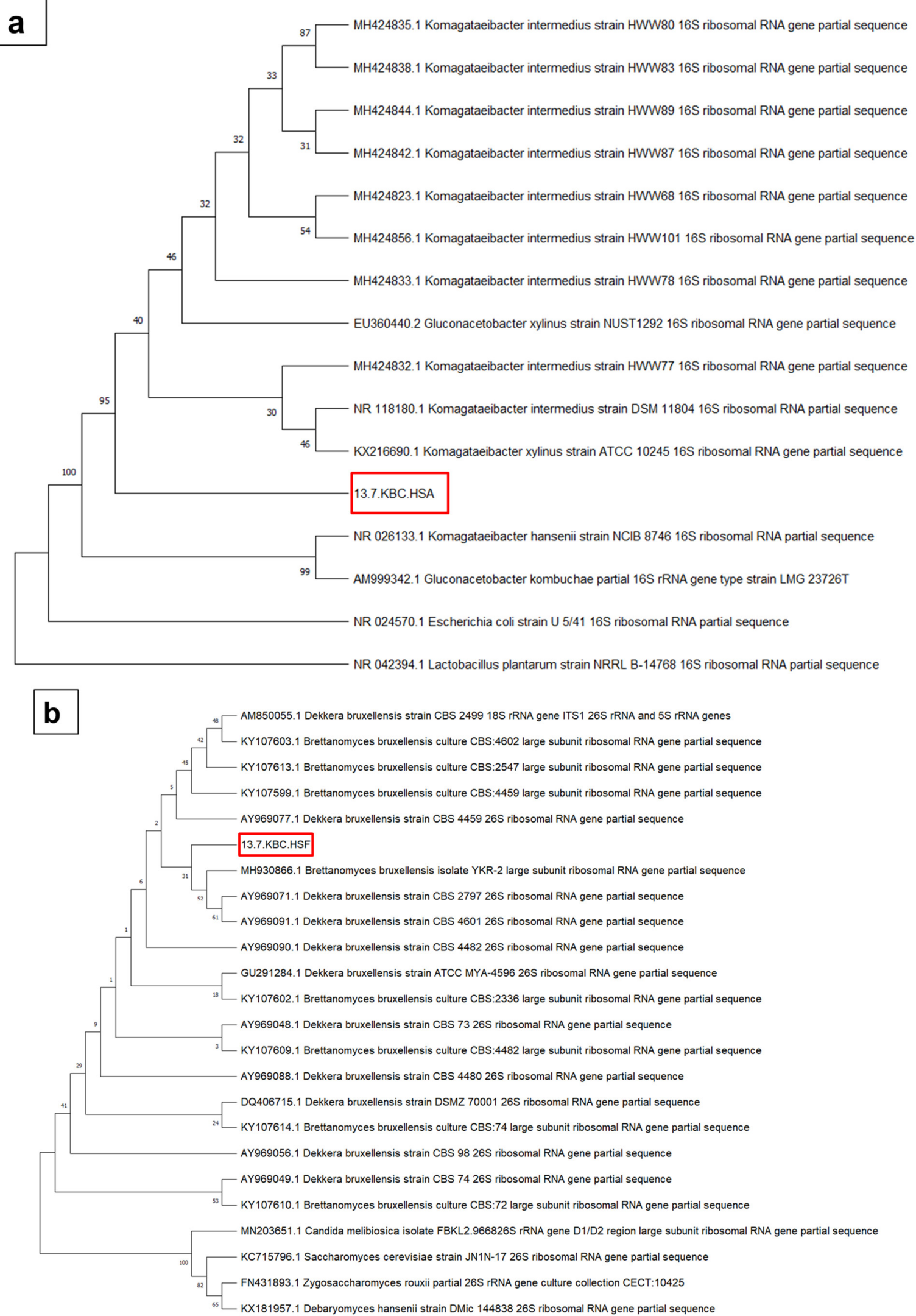

Figure 1. Neighbor-Joining tree of the sequencing result based after BLAST analysis. (a) Bacterial isolate's 16S rRNA sequence; (b) yeast isolate's $26 \mathrm{~S}$ rRNA sequence with closely identical sequences and several distant species. The tree was reconstructed using 500 bootstrapping. Red box (a) 13.7.KBC.HSA indicates the bacterial isolate and (b) 13.7.KBC.HSF indicates yeast isolate from the Kombucha culture. 


\subsection{Synergistic Growth of K. intermedius and D. bruxellensis in Co-Culture}

As two or more microbial species co-exist, a mutualistic or antagonistic interaction may occur since each microbe requires different nutrition and optimal growing conditions, which lead to different growth rates. To find out which types of interactions occur between $K$. intermedius and D. bruxellensis in the co-culture system, the population of both species in single and co-culture was compared.

During the first 3 days of single culture fermentation, K. intermedius multiplied at a specific growth rate of $0.188 \pm 0.01 \mathrm{~h}^{-1}$, which increased by $14.4 \%$ in co-culture to $0.215 \pm 0.01 \mathrm{~h}^{-1}$, suggesting a stimulatory effect of D. bruxellensis on K. intermedius growth (Table 2). In co-culture, $K$. intermedius maintained a relatively stable population during the first 12 days before it was decreased from $7.11 \log$ CFU/mL to $5.85 \log$ CFU/mL on day 15 . By contrast, when $D$. bruxellensis was absent, $K$. intermedius population started to decrease on day 9, from $6.52 \log \mathrm{CFU} / \mathrm{mL}$ to $3.42 \log \mathrm{CFU} / \mathrm{mL}$ on day 15 (Figure 2a).

Table 2. Specific growth rate $\mu\left(\mathrm{h}^{-1}\right)$, the sugar consumption rate $(\mathrm{g} / \mathrm{L} / \mathrm{d})$, initial production rate $(\mathrm{g} / \mathrm{L} / \mathrm{d})$, and total BC yield (g/L) of K. intermedius (bacteria) and D. bruxellensis (yeast) in single and co-culture.

\begin{tabular}{|c|c|c|c|c|}
\hline \multirow[b]{2}{*}{ Sample } & \multirow{2}{*}{$\begin{array}{l}\text { Specific Growth Rate } \\
\qquad \mu\left(h^{-1}\right)^{a}\end{array}$} & \multirow{2}{*}{$\begin{array}{l}\text { Sugar Consumption } \\
\text { Rate (g/L/day) }\end{array}$} & \multicolumn{2}{|c|}{ BC Production } \\
\hline & & & $\begin{array}{l}\text { Initial Production } \\
\text { Rate (g/L/day) }^{c}\end{array}$ & ${\text { Total Yield }(g / L)^{d}}^{d}$ \\
\hline $\begin{array}{l}\text { Single culture- } K \text {. } \\
\text { intermedius }\end{array}$ & $0.188 \pm 0.01$ & $15.9 \pm 0.01$ & $7.33 \pm 0.01$ & $22.0 \pm 0.01$ \\
\hline $\begin{array}{l}\text { Single culture- } D . \\
\text { bruxellensis }\end{array}$ & $0.213 \pm 0.18$ & $25.8 \pm 2.1$ & NA & NA \\
\hline Co-culture: & & $46.4 \pm 3.2$ & $5.50 \pm 0.5$ & $17.5 \pm 1.5$ \\
\hline K. intermedius & $0.215 \pm 0.01$ & NA & NA & NA \\
\hline D. bruxellensis & $0.223 \pm 0.01$ & NA & NA & NA \\
\hline
\end{tabular}

${ }_{a, c}$ Specific growth rate and initial BC production rate during the first 3 days of incubation. ${ }^{b}$ Initial sugar consumption rate during the first 4 days of incubation. ${ }^{d}$ Total yield produced after 15 days of incubation. Data measured for $10 \%$ inoculum size, NA: no assessment.

A similar stimulatory effect of co-culture was also observed on $D$. bruxellensis, indicated by an increase in specific growth rate by $4.69 \%$ from $0.213 \pm 0.18 \mathrm{~h}^{-1}$ to $0.223 \pm 0.01 \mathrm{~h}^{-1}$ during the first 3 days of fermentation (Table 2). In co-culture, D. bruxellensis constantly multiplied during the first 9 days, increasing its population from $5.68 \log \mathrm{CFU} / \mathrm{mL}$ to 8.80 $\log \mathrm{CFU} / \mathrm{mL}$. While during the same period, $D$. bruxellensis in single culture propagated slower, increasing its population only by $\sim 1 \log \mathrm{CFU} / \mathrm{mL}$ from $6.05 \log \mathrm{CFU} / \mathrm{mL}$ to 7.18 $\log \mathrm{CFU} / \mathrm{mL}$ (Figure $2 \mathrm{~b}$ ). Similar synergistic growth has also been observed between other bacterial and yeast species involved in soy sauce [36] and milk [37] fermentation. Such synergistic interaction could be associated with the production of metabolites such as pyruvate, amino acids, and vitamins, essential for one's population growth. In addition, the transformation of potential inhibitory substances into other compounds that are less toxic to one's population growth could also explain such synergistic interaction [38].

\subsection{The Effect of Co-Culture on Reducing Sugar Content}

Yeast has been known as an important invertase producer that breaks down sucrose into reducing sugars, which are more accessible to any microbial members of the Kombucha consortium. BC-producing bacteria will subsequently use these reducing sugars to produce organic acids and $\mathrm{BC}$ as a floating pellicle. In this study, the reducing sugar consumption rates by K. intermedius and D. bruxellensis in both single and co-culture were monitored. 

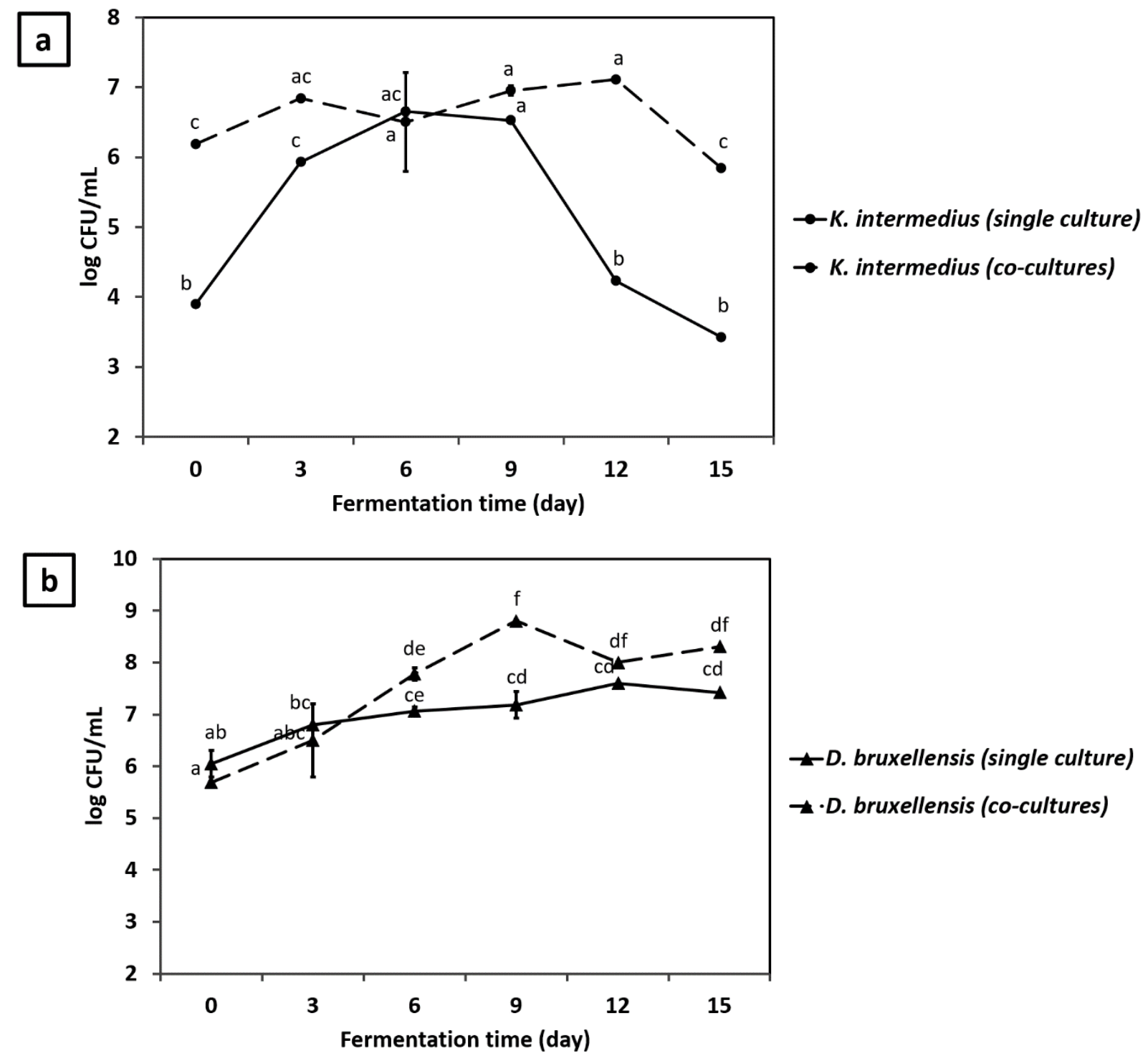

Figure 2. The growth of (a) K. intermedius and (b) D. bruxellensis as single and co-culture. Culture conditions: media composition, $150 \mathrm{~g} / \mathrm{L}$ molasses, $500 \mathrm{mg} / \mathrm{L}$ caffeine, acetate buffer $(200 \mathrm{mM}, \mathrm{pH} 4.75)$; inoculum size, $10 \%$ v/v; K. intermedius: D. bruxellensis ratio, $1: 1$; temperature, $30{ }^{\circ} \mathrm{C}$. Means with different letters are significantly different $(p<0.05)$.

As shown in Figure 3a, maximum reducing sugar consumption by K. intermedius and D. bruxellensis in single culture occurred on day 8 followed by a plateau. However, the maximum amount of reducing sugars consumed by K. intermedius only reached $36 \%$, while D. bruxellensis reached up to $82 \%$, leaving $\sim 50 \mathrm{~g} / \mathrm{L}$ and $\sim 14 \mathrm{~g} / \mathrm{L}$ reducing sugars in the media, respectively. The results confirm that $D$. bruxellensis could consume higher reducing sugar than K. intermedius, which might explain its survival during fermentation (Figure 2a). A higher reducing sugar consumption rate by D. bruxellensis was expected since it can break down sucrose into reducing sugars, increasing their availability to both microbes. However, the increase in reducing sugar concentration could not be observed, suggesting that the consumption rate exceeded the production rate, resulting in a constant decrease in reducing sugar concentration during the fermentation. 

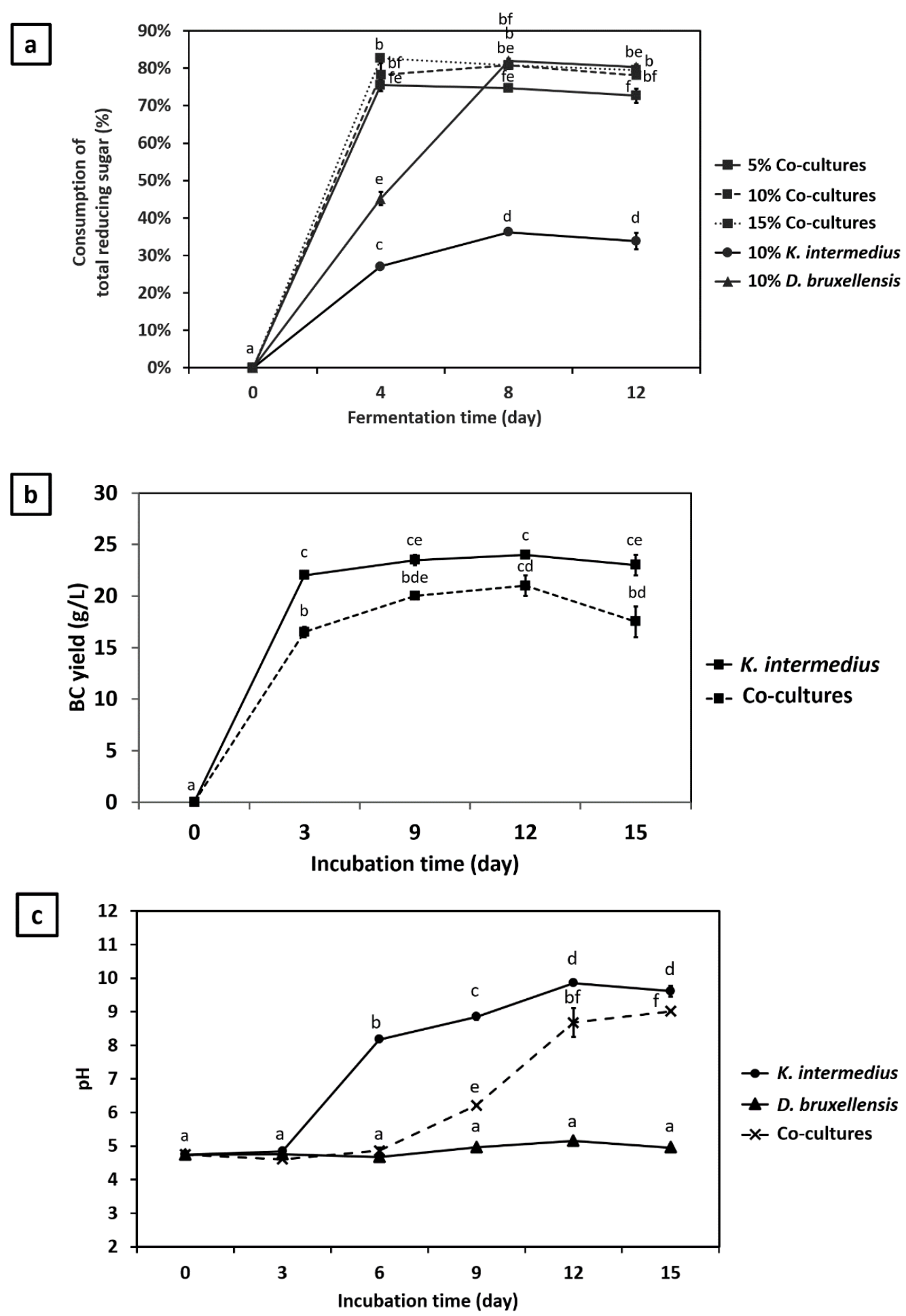

Figure 3. (a) Reducing sugar consumption by single and co-culture varying in inoculum sizes (5\%, 10\%, 15\% v/v); (b) BC yield and (c) $\mathrm{pH}$ changes during single and co-culture fermentation using inoculum size of $10 \% v / v$. Culture conditions: media composition, $150 \mathrm{~g} / \mathrm{L}$ molasses, $500 \mathrm{mg} / \mathrm{L}$ caffeine, acetate buffer ( $200 \mathrm{mM}, \mathrm{pH} 4.75) ;$ K. intermedius: D. bruxellensis ratio, $1: 1$; temperature, $30^{\circ} \mathrm{C}$. Means with different letters are significantly different $(p<0.05)$.

The reducing sugar consumption rates of $K$. intermedius and D. bruxellensis in single and co-culture during the first 4 days of fermentation were calculated and compared as presented in Table 2. In single culture, the sugar consumption rate was $62.3 \%$ higher for D. bruxellensis as compared to K. intermedius, which was about $25.8 \pm 2 \mathrm{~g} / \mathrm{L} /$ day and $15.9 \pm 0.01 \mathrm{~g} / \mathrm{L} /$ day, respectively. The consumption rate for D. bruxellensis and $K$. 
intermedius increased in co-culture by $79.8 \%$ and $191 \%$, respectively, to $46.4 \pm 3.2 \mathrm{~g} / \mathrm{L} /$ day, slightly higher than the sum of their individual consumption rate. Such an increased consumption rate caused the depletion of nearly $80 \%$ of total reducing sugar in co-culture within the first 4 days of fermentation (Figure 3a). The result was in agreement with previous studies reporting the importance D. bruxellensis to make sugars more available to K. intermedius $[14,16,17]$.

\subsection{The Effect of Co-Culture on $\mathrm{pH}$ Changes}

In single culture, $K$. intermedius caused a significant $\mathrm{pH}$ increase from 4.74 to 9.61, while D. bruxellensis maintained a constant $\mathrm{pH}(\sim 4.8)$ throughout fermentation. On the other hand, the $\mathrm{pH}$ increased more slowly in co-culture, as it took 12 days for the co-culture to reach $\mathrm{pH}>$ 8.0, whereas it took only 6 days for the single culture. This observation could be attributed to $D$. bruxellensis' ability to produce acetic acid [39]. However, $\mathrm{pH}$ increase was unexpected with the presence of $K$. intermedius in both single and co-culture, since acetic acid bacteria of the Komagataeibacter genus are well known for their ability to produce various organic acids, such as acetic acid, gluconic acid, and glucuronic acid causing the $\mathrm{pH}$ to decrease. Although acid production is less significant than K. xylinus, a decrease in $\mathrm{pH}$ was previously observed by Fernández et al. [2]. Most investigations performed on BC production by $K$. intermedius have reported $\mathrm{pH}$ reduction throughout fermentation. For instance, Lin et al. [21] conducted a fermentation using K. intermedius FST213-1 in an HS medium with an initial $\mathrm{pH}$ of 8.0 and found the $\mathrm{pH}$ to drop to $\sim 4.0$ after 4 days, which remained constant until the end of the fermentation. Furthermore, Fernández et al. [2] reported a pH reduction by one order of magnitude within $96 \mathrm{~h}$ when $K$. intermedius JF2 was cultivated in HS and HS-glucosemannitol media with an initial $\mathrm{pH}$ of 5.5 and 6.0, respectively. Similarly, a decreasing $\mathrm{pH}$ trend from 4.5 to 3.0 was reported by Nguyen et al. [17] during Kombucha fermentation using Gluconacetobacter intermedius KN89 and D. bruxellensis co-culture due to acid production. A $\mathrm{pH}$ reduction was also observed using G. intermedius SNT-1 in HS medium supplemented with pre-treated molasses as a carbon source [1].

The increasing trend in $\mathrm{pH}$ observed in this study could be attributed to sodium acetate in the acetate buffer used, as previously reported by Jeffery et al. [40]. The finding was confirmed in the present study as the $\mathrm{pH}$ decreased significantly $(p<0.05)$ from 5.98 to 4.27 within 7 days in the absence of acetate buffer (Figure 4 ). In contrast, a significant increase in $\mathrm{pH}$ was observed in its presence, regardless of the starting $\mathrm{pH}(4.0,4.75$, and 5.5). Nevertheless, the reason that acetate buffer causes the $\mathrm{pH}$ of molasses medium to rise warrants future investigations.

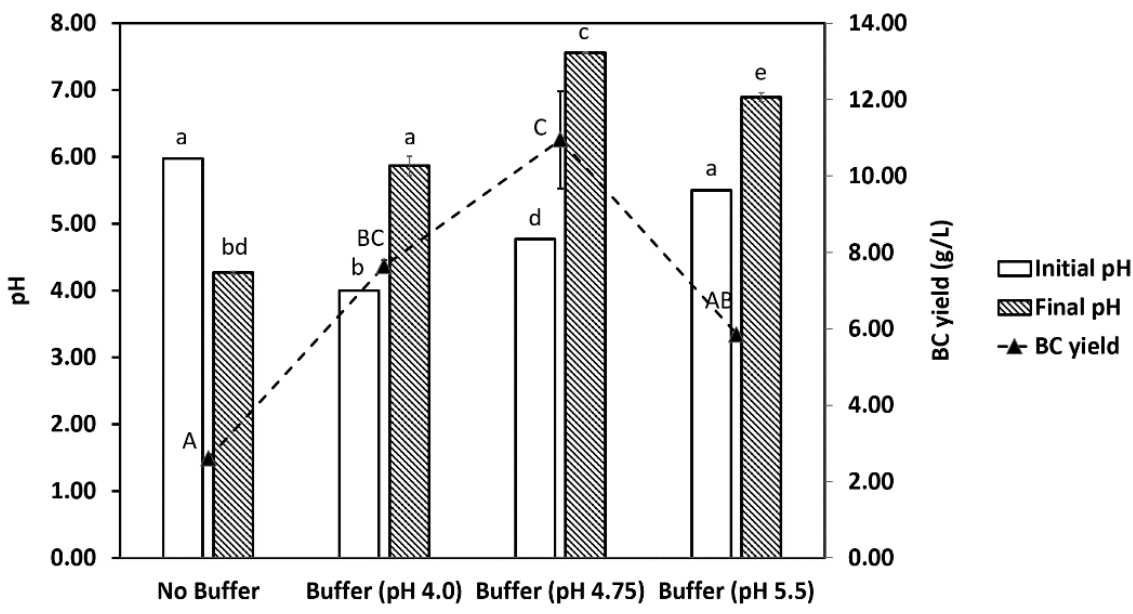

Figure 4. Effects of acetate buffer on $\mathrm{pH}$ and $\mathrm{BC}$ yield after 7 days of co-culture fermentation. Culture conditions: media composition, $150 \mathrm{~g} / \mathrm{L}$ molasses, $500 \mathrm{mg} / \mathrm{L}$ caffeine, acetate buffer (no acetate buffer; $200 \mathrm{mM}$, pH 4.0, 4.75, 5.5); inoculum size, 10\% v/v; K. intermedius: D. bruxellensis ratio, 1:1; temperature, $30^{\circ} \mathrm{C}$. Different upper-case letters indicate significant differences $(p<0.05)$ in BC yields. 


\subsection{The Effect of Co-Culture on BC Production}

$\mathrm{BC}$ production by $\mathrm{K}$. intermedius in single and co-culture are shown in Figure 3c. Significant growth of the BC layer in both single and co-culture was observed during the first 3 days of fermentation. However, the production rate was higher in single culture $(7.33 \mathrm{~g} / \mathrm{L} /$ day) than in co-culture $(5.5 \mathrm{~g} / \mathrm{L} /$ day $)$, producing $22 \mathrm{~g} / \mathrm{L}$ and $16.5 \mathrm{~g} / \mathrm{L}$ of $\mathrm{BC}$ by day 3 , respectively (Table 2). After 3 days, $\mathrm{BC}$ growth in single culture reached a plateau, while it lasted until day 12 in co-culture. By the end of fermentation, the total BC yields obtained in single and co-culture were $22 \mathrm{~g} / \mathrm{L}$ and $17.5 \mathrm{~g} / \mathrm{L}$, respectively. The results suggest that the presence of $D$. bruxellensis could cause a significant reduction $(p<0.05)$ in BC production ( $24 \%$ ) despite its stimulatory effect on $K$. intermedius growth (Figure $2 a$ ). In co-culture, $D$. bruxellensis might have utilized a significant portion of reducing sugar, limiting the amount of sugar available for K. intermedius to convert into BC. Another possible reason is that $D$. bruxellensis might have stimulated $K$. intermedius to convert a higher proportion of reducing sugar into acid production instead of $B C$, as previously reported by Nguyen et al. [17]. They suggest that D. bruxellensis can increase the level of acetic acid in the media that could provoke a feedback inhibition in the glycolysis pathway of $K$. intermedius, promoting glucose conversion into glucuronic acid. The two possibilities may explain why the $\mathrm{pH}$ during the early to mid-stage fermentation was more acidic in co-culture than in single culture (Figure 3c). Furthermore, the relatively lower $\mathrm{pH}$ in co-culture might provide a less favorable environment for $\mathrm{K}$. intermedius to produce BC. The results shown in Figure 4 further confirm that the highest BC yield $(13.19 \mathrm{~g} / \mathrm{L})$ was obtained when the $\mathrm{pH}$ increased to 7.56 . In contrast, the lowest $\mathrm{BC}$ yield $(2.60 \mathrm{~g} / \mathrm{L})$ was achieved when the $\mathrm{pH}$ dropped to 4.27 . This result was in accordance with the study conducted by Lin et al. [21], which demonstrated the ability of K. intermedius FST213-1 to produce BC within the range of $\mathrm{pH} 4-9$, with $\mathrm{pH} 8$ resulting in the highest $\mathrm{BC}$ yield $(1.2 \mathrm{~g} / \mathrm{L})$. Based on these results, it could be suggested that the $\mathrm{BC}$ production is more favorable in alkaline conditions, which in this case, could be achieved by adding acetate buffer into the media. However, the underlying mechanisms of how acetate buffer increases $\mathrm{pH}$ and eventually the $\mathrm{BC}$ yield require further investigation.

\section{Conclusions}

In this study, the effect of $D$. bruxellensis on $K$. intermedius growth and $\mathrm{BC}$ production was investigated. The results showed that $D$. bruxellensis could prolong $K$. intermedius' stationary phase up to 12 days and maintain a $2.43 \log \mathrm{CFU} / \mathrm{mL}$ higher population by the end of the fermentation process. However, the $\mathrm{BC}$ production was compromised as the $\mathrm{BC}$ yield decreased by $\sim 24 \%$ in co-culture. Moreover, an unusual increasing $\mathrm{pH}$ trend was observed as K. intermedius proliferated, associated with higher BC production. Although $K$. intermedius growth could be stimulated, further investigation should be conducted to find an optimum inoculation procedure, to prevent $D$. bruxellensis from interfering with the $\mathrm{BC}$ production.

Author Contributions: Conceptualization, P.V.P.D., K.K. and S.A.; methodology, P.V.P.D., K.K. and S.A.; software, R.N.; validation, P.V.P.D., K.K. and S.A.; formal analysis, A.B. and R.N.; investigation, A.B.; resources, S.A.; data curation, P.V.P.D., K.K. and S.A.; writing-original draft preparation, P.V.P.D.; writing -review and editing, K.K., S.A., R.N. and M.J.T.; visualization, P.V.P.D., R.N. and S.A.; supervision, P.V.P.D., K.K. and S.A.; project administration, P.V.P.D., K.K. and S.A.; funding acquisition, P.V.P.D., K.K. and S.A. All authors have read and agreed to the published version of the manuscript.

Funding: This research was funded by Indonesian Ministry Of Research And Technology/National Research And Innovation Agency, grant number 009/LL3/PG/2020.

Institutional Review Board Statement: Not applicable.

Informed Consent Statement: Not applicable. 
Acknowledgments: The authors would like to thank Jeffrey Young and Ferren Pratama for the technical assistance of this work.

Conflicts of Interest: The authors declare no conflict of interest. The funders had no role in the design of the study; in the collection, analyses, or interpretation of data; in the writing of the manuscript, or in the decision to publish the results.

\section{References}

1. Tyagi, N.; Suresh, S. Production of cellulose from sugarcane molasses using Gluconacetobacter intermedius SNT-1: Optimization \& characterization. J. Clean. Prod. 2016, 112, 71-80. [CrossRef]

2. Fernández, J.; Morena, A.G.; Valenzuela, S.V.; Pastor, F.I.J.; Díaz, P.; Martínez, J. Microbial Cellulose from a Komagataeibacter intermedius Strain Isolated from Commercial Wine Vinegar. J. Polym. Environ. 2019, 27, 956-967. [CrossRef]

3. Ul-Islam, M.; Khan, T.; Park, J.K. Water holding and release properties of bacterial cellulose obtained by in situ and ex situ modification. Carbohydr. Polym. 2012, 88, 596-603. [CrossRef]

4. Azeredo, H.M.C.; Barud, H.; Farinas, C.S.; Vasconcellos, V.M.; Claro, A.M. Bacterial Cellulose as a Raw Material for Food and Food Packaging Applications. Front. Sustain. Food Syst. 2019, 3, 7. [CrossRef]

5. Purwadaria, T.; Gunawan, L.; Gunawan, A.W. The production of nata colored by Monascus purpureus J1 pigments as functional food. Microbiol. Indones. 2010, 4, 6-10. [CrossRef]

6. Lin, S.B.; Chen, L.C.; Chen, H.H. Physical characteristics of surimi and bacterial cellulose composite gel. J. Food Process Eng. 2011, 34, 1363-1379. [CrossRef]

7. Lin, K.W.; Lin, H.Y. Quality Characteristics of Chinese-style Meatball Containing Bacterial Cellulose (Nata). J. Food Sci. 2004, 69, SNQ107-SNQ111. [CrossRef]

8. Paximada, P.; Tsouko, E.; Kopsahelis, N.; Koutinas, A.A.; Mandala, I. Bacterial cellulose as stabilizer of o/w emulsions. Food Hydrocoll. 2016, 53, 225-232. [CrossRef]

9. Fijałkowski, K.; Peitler, D.; Rakoczy, R.; Zywicka, A. Survival of probiotic lactic acid bacteria immobilized in different forms of bacterial cellulose in simulated gastric juices and bile salt solution. LWT 2016, 68, 322-328. [CrossRef]

10. Bayazidi, P.; Almasi, H.; Asl, A.K. Immobilization of lysozyme on bacterial cellulose nanofibers: Characteristics, antimicrobial activity and morphological properties. Int. J. Biol. Macromol. 2018, 107, 2544-2551. [CrossRef]

11. Chang, S.T.; Chen, L.C.; Lin, S.B.; Chen, H.H. Nano-biomaterials application: Morphology and physical properties of bacterial cellulose/gelatin composites via crosslinking. Food Hydrocoll. 2012, 27, 137-144. [CrossRef]

12. Salari, M.; Sowti Khiabani, M.; Rezaei Mokarram, R.; Ghanbarzadeh, B.; Samadi Kafil, H. Development and evaluation of chitosan based active nanocomposite films containing bacterial cellulose nanocrystals and silver nanoparticles. Food Hydrocoll. 2018, 84, 414-423. [CrossRef]

13. Çakar, F.; Kati, A.; Özer, I.; Demirbağ, D.D.; Şahin, F.; Aytekin, A.Ö. Newly developed medium and strategy for bacterial cellulose production. Biochem. Eng. J. 2014, 92, 35-40. [CrossRef]

14. May, A.; Narayanan, S.; Alcock, J.; Varsani, A.; Maley, C.; Aktipis, A. Kombucha: A novel model system for cooperation and conflict in a complex multi-species microbial ecosystem. PeerJ 2019, 7, e7565. [CrossRef]

15. Villarreal-Soto, S.A.; Beaufort, S.; Bouajila, J.; Souchard, J.P.; Taillandier, P. Understanding Kombucha Tea Fermentation: A Review. J. Food Sci. 2018, 83, 580-588. [CrossRef] [PubMed]

16. Jayabalan, R.; Malbaša, R.V.; Lončar, E.S.; Vitas, J.S.; Sathishkumar, M. A review on kombucha tea-microbiology, composition, fermentation, beneficial effects, toxicity, and tea fungus. Compr. Rev. Food Sci. Food Saf. 2014, 13, 538-550. [CrossRef] [PubMed]

17. Nguyen, N.K.; Nguyen, P.B.; Nguyen, H.T.; Le, P.H. Screening the optimal ratio of symbiosis between isolated yeast and acetic acid bacteria strain from traditional kombucha for high-level production of glucuronic acid. LWT Food Sci. Technol. 2015, 64, 1149-1155. [CrossRef]

18. Tran, T.; Grandvalet, C.; Verdier, F.; Martin, A.; Alexandre, H.; Tourdot-Maréchal, R. Microbial Dynamics between Yeasts and Acetic Acid Bacteria in Kombucha: Impacts on the Chemical Composition of the Beverage. Foods 2020, 9, 963. [CrossRef]

19. Kumar, S.; Stecher, G.; Li, M.; Knyaz, C.; Tamura, K. MEGA X: Molecular Evolutionary Genetics Analysis across Computing Platforms. Mol. Biol. Evol. 2018, 35, 1547-1549. [CrossRef]

20. Doran, P.M. Bioprocess Engineering Principles, 2nd ed.; Academic Press: Cambridge, UK, 2013; ISBN 9780080917702.

21. Lin, S.P.; Huang, Y.H.; Hsu, K.D.; Lai, Y.J.; Chen, Y.K.; Cheng, K.C. Isolation and identification of cellulose-producing strain Komagataeibacter intermedius from fermented fruit juice. Carbohydr. Polym. 2016, 151, 827-833. [CrossRef]

22. Gaggìa, F.; Baffoni, L.; Galiano, M.; Nielsen, D.S.; Jakobsen, R.R.; Castro-Mejía, J.L.; Bosi, S.; Truzzi, F.; Musumeci, F.; Dinelli, G.; et al. Kombucha beverage from green, black and rooibos teas: A comparative study looking at microbiology, chemistry and antioxidant activity. Nutrients 2019, 11, 1. [CrossRef]

23. Coton, M.; Pawtowski, A.; Taminiau, B.; Burgaud, G.; Deniel, F.; Coulloumme-Labarthe, L.; Fall, A.; Daube, G.; Coton, E. Unraveling microbial ecology of industrial-scale Kombucha fermentations by metabarcoding and culture-based methods. FEMS Microbiol. Ecol. 2017, 93, 1-16. [CrossRef]

24. Teoh, A.L.; Heard, G.; Cox, J. Yeast ecology of Kombucha fermentation. Int. J. Food Microbiol. 2004, 95, 119-126. [CrossRef]

25. Serra Colomer, M.; Funch, B.; Forster, J. The raise of Brettanomyces yeast species for beer production. Curr. Opin. Biotechnol. 2019, 56, 30-35. [CrossRef] 
26. Oro, L.; Canonico, L.; Marinelli, V.; Ciani, M.; Comitini, F. Occurrence of Brettanomyces bruxellensis on Grape Berries and in Related Winemaking Cellar. Front. Microbiol. 2019, 10, 415. [CrossRef]

27. Morrissey, W.F.; Davenport, B.; Querol, A.; Dobson, A.D.W. The role of indigenous yeats in traditional Irish cider fermentations. J. Appl. Microbiol. 2004, 97, 647-655. [CrossRef]

28. Smith, B.D.; Divol, B. Brettanomyces bruxellensis, a survivalist prepared for the wine apocalypse and other beverages. Food Microbiol. 2016, 59, 161-175. [CrossRef] [PubMed]

29. Avramova, M.; Cibrario, A.; Peltier, E.; Coton, M.; Coton, E.; Schacherer, J.; Spano, G.; Capozzi, V.; Blaiotta, G.; Salin, F.; et al. Brettanomyces bruxellensis population survey reveals a diploid-triploid complex structured according to substrate of isolation and geographical distribution. Sci. Rep. 2018, 8, 1-13. [CrossRef] [PubMed]

30. Dimopoulou, M.; Renault, M.; Dols-Lafargue, M.; Albertin, W.; Herry, J.M.; Bellon-Fontaine, M.N.; Masneuf-Pomarede, I. Microbiological, biochemical, physicochemical surface properties and biofilm forming ability of Brettanomyces bruxellensis. Ann. Microbiol. 2019, 69, 1217-1225. [CrossRef]

31. Borneman, A.R.; Zeppel, R.; Chambers, P.J.; Curtin, C.D. Insights into the Dekkera bruxellensis Genomic Landscape: Comparative Genomics Reveals Variations in Ploidy and Nutrient Utilisation Potential amongst Wine Isolates. PLoS Genet. 2014, 10, e1004161. [CrossRef] [PubMed]

32. Crauwels, S.; Zhu, B.; Steensels, J.; Busschaert, P.; De Samblanx, G.; Marchal, K.; Willems, K.A.; Verstrepen, K.J.; Lievens, B. Assessing genetic diversity among Brettanomyces yeasts by DNA fingerprinting and whole-genome sequencing. Appl. Environ. Microbiol. 2014, 80, 4398-4413. [CrossRef] [PubMed]

33. Woolfit, M.; Rozpędowska, E.; Piškur, J.; Wolfe, K.H. Genome survey sequencing of the wine spoilage yeast Dekkera (Brettanomyces) bruxellensis. Eukaryot. Cell 2007, 6, 721-733. [CrossRef]

34. De Barros Pita, W.; Leite, F.C.B.; De Souza Liberal, A.T.; Simões, D.A.; De Morais, M.A. The ability to use nitrate confers advantage to Dekkera bruxellensis over S. cerevisiae and can explain its adaptation to industrial fermentation processes. Antonie Leeuwenhoek 2011, 100, 99-107. [CrossRef]

35. Tiukova, I.A.; Petterson, M.E.; Tellgren-Roth, C.; Bunikis, I.; Eberhard, T.; Pettersson, O.V.; Passoth, V. Transcriptome of the Alternative Ethanol Production Strain Dekkera bruxellensis CBS 11270 in Sugar Limited, Low Oxygen Cultivation. PLoS ONE 2013, 8, e58455. [CrossRef] [PubMed]

36. Devanthi, P.V.P.; Linforth, R.; Onyeaka, H.; Gkatzionis, K. Effects of co-inoculation and sequential inoculation of Tetragenococcus halophilus and Zygosaccharomyces rouxii on soy sauce fermentation. Food Chem. 2018, 240, 1-8. [CrossRef]

37. Arakawa, K.; Miyamoto, M.; Miyamoto, T. Interaction between lactic acid bacteria and yeasts in airag, an alcoholic fermented milk. Anim. Sci. J. 2013, 84, 66-74. [CrossRef]

38. Schifferdecker, A.J.; Dashko, S.; Ishchuk, O.P.; Piškur, J. The wine and beer yeast Dekkera bruxellensis. Yeast 2014, $31,323-332$. [CrossRef]

39. Freer, S.N.; Dien, B.; Matsuda, S. Production of acetic acid by Dekkera/Brettanomyces yeasts under conditions of constant pH. World J. Microbiol. Biotechnol. 2003, 19, 101-105. [CrossRef]

40. Jeffery, J.; Kock, J.L.F.; Du Preez, J.C.; Bareetseng, A.S.; Coetzee, D.J.; Botes, P.J.; Botha, A.; Schewe, T.; Nigam, S. Effect of acetate and $\mathrm{pH}$ on sunflower oil assimilation by Mucor circinelloides f. circinelloides. Syst. Appl. Microbiol. 1999, 22, 156-160. [CrossRef] 